\title{
Diversity Analysis among Fusarium oxysporum F. Sp. cumini Isolates Using ISSR Markers, Spore Morphology and Pathogenicity
}

\author{
Bhagwat Nawade $^{1 *}$, J.R. Talaviya, U.M. yys $^{2}$, K.B. Jadeja ${ }^{2}$ and B.A. Golakiya ${ }^{1}$ \\ ${ }^{1}$ Department of Biotechnology, College of Agriculture, Junagadh Agricultural University, \\ 362001 Junagadh, Gujarat, India \\ ${ }^{2}$ Department of Plant Pathology, College of Agriculture, Junagadh Agricultural University, \\ 362001 Junagadh, Gujarat, India \\ *Corresponding author
}

A B S T R A C T

\begin{tabular}{|l|}
\hline K e y w o r d s \\
Cumin wilt, Genetic \\
diversity, Inter \\
Simple Sequence \\
Repeat, Virulence. \\
\hline Article Info \\
\hline $\begin{array}{l}\text { Accepted: } \\
\text { 02 March } 2017 \\
\text { Available Online: } \\
\text { 10 April } 2017\end{array}$ \\
\hline
\end{tabular}

Fusarium oxysporum f. sp. cumini is a serious disease of cumin (Cuminum cyminum L.). Ten isolates of $F$. oxysporum $\mathrm{f}$. sp. cumini were isolated from major cumin growing districts of Gujarat state to compare molecular methods over traditional for differentiation among the isolates of pathogen. The average $98.70 \%$ of polymorphism was recorded for all the 11 ISSR primers. The polymorphic information content (PIC) value ranged from 0.571 to 0.831 with an average of 0.739 per primer. The IISR primers grouped majority of the isolates based on their geographical location. The microconidia and macroconidia were 0-1 and 2-5 septa respectively and hyaline. All isolates showed varied levels of virulence. The ISSR analysis grouping does not show correlation with spore morphology and pathogenicity of the isolates.

\section{Introduction}

Cumin (Cuminum cyminum L.) is a herbaceous, dicotyledonous annual plant, diploid $(2 \mathrm{n}=2 \mathrm{x}=14)$ and allogam with hermaphrodite flowers. Cumin is extensively used in cuisines around the world.Recent studies have indicated its pharmaceutical and medicinal importance (Dhartiben et al., 2016). Indian cumin production for the crop year 2015-16 is estimated to be around 3,72, 290 tonnes against the last year production of 295 thousand tonnes. Current crop year production is 7 percent less compared to last three year's average production of 329 thousand tonnes (Spice Board, India, 2016). India is the leading producer (75\% of world production), exporter and consumer of cumin in the world. It is also cultivated in Syria, Turkey, Egypt, Libya, Iran, China, Pakistan and Mexico (Mohammadi and Mofrad, 2009). The Vietnam, UAE, US, Egypt, UK and Brazil are the leading importers of Indian origin cumin seeds. Gujarat state share 59\% of Indian production and Surendranagar is the leading district (Spice Board, India, 2016). Because of its low water requirements, farmers are interested in cultivation of cumin in drought affected areas, where most of the other crop plants cannot be grown economically (Talaviya et al., 2014).

The fungus Fusarium oxysporum f. sp. cumini Prasad and Patel was first reported by Patel et 
al., (1957) as a wilt causing pathogen in cumin. Since the pathogen is soil borne and difficult to eradicate, as fungal chlamydospores survive in soil up to 6 years even in the absence of the host plant (Haware et al., 1996).

The differentiation among the isolates of pathogen by traditional methods, involve pathogenicity, cultural characters and microstructure measurement are laborintensive, time-consuming, and are not perfect as it is in DNA based differentiation. DNA based techniques have increasingly become the tool of choice for understanding the genetic diversity and phylogeny of Fusarium species (SELIM and Zanaty, 2014). The ISSR (Inter Simple Sequence Repeat) technique has been successfully used to identify variability within F. oxysporum (Baysal et al., 2010; Mohammadi et al., 2011; Bayraktar and Dolar, 2011). The use of molecular markers offers significant advantages over traditional methods since they are not affected by the environmental conditions as well as they are rapid and large numbers of samples can be processed in a short time by these methods. Present study was aimed to study genetic diversity and correlation between genetic variability, spore morphology and pathogenicity of $F$. oxysporum f. sp. cumini isolates.

\section{Materials and Methods}

\section{Isolation, purification and spore morphology}

Cumin plants, naturally infected and showing typical wilt symptoms were collected from farmer's fields of Gujarat state. The resulting fungal culture was purified by hyphal tip method (Nelson et al., 1983). Purified culture was maintained by storing it under refrigeration $\left(10^{\circ} \mathrm{C}\right)$. Identification of the pathogen was done using colony characteristics and spore morphology (Booth, 1971). The measurements of conidia and conidiophores were made with the help of ocular micrometer (Sinclair and Dhingra, 1985). Scanning electron microscope (SEM) was also used to study spore shape and size (Fig. 2). Samples were prepared using the Critical Point Drier.

\section{Pathogenicity test}

Pathogenicity tests for all isolates of Fusarium oxysporum f. sp. cumini were done on commonly cultivated cumin variety ' $\mathrm{GC}$ 4'. The inoculants were obtained from cultures grown on potato dextrose broth for one week. The planting media was composed of soil, manure (cow dung) and sand in the ratio $2: 1: 1$ by volume. The planting media was steam sterilized at $80^{\circ} \mathrm{C}$ overnight, allowed to cool. Fifty $\mathrm{ml}$ of suspension of each isolate was mixed with steam-sterilized soil and then 25 seeds were sown in each pot (contained $3 \mathrm{~kg}$ soil) after surface sterilization with $0.1 \%$ mercuric chloride solution for one minute followed by water wash. Non inoculated soil planted with cumin seeds were used as controls. After germination 20 plants were kept in each pot. Watering was done as and when needed. The plants were observed regularly for the appearance and development of disease symptoms. As the symptoms of disease appeared, the fungus was re isolated from this plant and brought to pure culture, which was later compared with the original one. Total count of wilted plants up to maturity was recorded and finally disease $\%$ was calculated for each pot set.

\section{Molecular characterization}

Total genomic DNA was extracted by the method of Murray and Thompson (1980) with minor modifications. The reagents and buffers for DNA isolation were prepared as per 
Sambrook et al., (1989). The genetic diversity present at molecular level in $F$. oxysporum f. sp. cumini was studied using twenty ISSR primers. Taq polymerase, dNTP, 10X reaction buffer and $1 \mathrm{~kb}$ ladder were taken from Bangalore Genei, India. The polymerase chain reaction (PCR) was performed by using Eppendrof $\mathrm{ep}^{\mathrm{TM}}$ gradient thermal cycler. PCR reaction $(25 \mu \mathrm{l})$ consisted of $75 \mathrm{ng}$ template DNA, 1.0 unit Taq polymerase, $2.5 \mathrm{mM}$ of $\mathrm{MgCl}_{2}, 0.2 \mathrm{mM}$ of each dNTP and $18.0 \mathrm{pmol}$ of primer in $10 \mathrm{X}$ reactions buffer. The PCR was performed with $94^{\circ} \mathrm{C}$ for $5 \mathrm{~min}$ for initial denaturation followed by 35 cycles of denaturation at $94^{\circ} \mathrm{C}$ for $45 \mathrm{sec}$., annealing at $\pm 2^{0} \mathrm{C}$ Tm for $1 \mathrm{~min}$. and extension at $72^{\circ} \mathrm{C}$ for $1.30 \mathrm{~min}$. with final extension of $72^{\circ} \mathrm{C}$ for 7 min. Polymorphism of amplicons was tested by agarose $(1.5 \%)$ gel electrophoresis. One kb ladder was used as marker.

Polymorphic information content (PIC) for ISSR was calculated on the basis of allele frequency using following formula (Anderson et al., 1993). ISSR primer index (IPI) was generated by multiplying the PIC values of all the markers amplified by the same primer. The obtained data subsequently analyzed using NTSYSpc version 2.02 (Rohlf, 1998). Dendrogram constructed using UPGMA (Unweighted Pair-Group Method with Arithmetic Averages) with Jaccard's similarity coefficient (Table 3).

\section{Results and Discussion}

\section{Cultural characteristics}

Microscopic observation revealed that the microconidia in all isolates were small, one to two celled and hyaline with oval to reniform and oval to oblong with slightly curved shape. Its length ranged from 3.48-17.38 $\mu \mathrm{m}$, while the width ranged from 2.30-4.55 $\mu \mathrm{m}$. Macroconidia in all these isolates were long, slightly curved or boat shaped, variable in size and smoothly rounded or pointed at the tip, mostly with 2-5 septa and hyaline in colour. Its length ranged from 16.89 to 59.30 $\mu \mathrm{m}$, while the width ranged from 4.08 to 6.98 $\mu \mathrm{m}$. Chlamydospores were thick walled, hyaline in colour, varied in shape, produced intercalary and terminal, single and in pair or in chain (Table 2). Suthar and Bhat (2011) observed the size of macro-conidia in the range of $28.0-30.5 \times 3.5-5.25 \mu \mathrm{m}$ and the micro-conidia in the range of $9.5-12.5 \times 3.5-$ $5.25 \mu \mathrm{m}$.

\section{Pathogenicity test}

All 10 isolates of Fusarium oxysporum f. sp. cumini were found to incite disease to varying levels. Symptoms observed on the infected plants were toppling of upper top leaves, followed lower branches and finally whole plant dried. Root symptoms include reduced growth with marked brown discoloration, tap root tips that are damaged and proliferation of secondary roots above the area of tap root injury. There were no symptoms observed on the un-inoculated cumin grown under the same condition. Junagadh and Dhrangadhra isolates showed highest $\%$ of pathogenicity, while lowest \% pathogenicity was recorded in Kadachh isolate. Isolates viz., Vadod, Rajgadh and Virpur had medium \% pathogenicity. Lower \% of pathogenicity was showed by Pandri, Sayla, Kotada Sangani and Keshod isolate (Table 2).

\section{Inter simple sequence repeat analysis}

Among 20 ISSR primers screened, 11 primers amplified a total of 56 bands out of which 55 bands alleles ${ }^{-1}$ were polymorphic with an average of 5.09 bands per primer and out of 55 polymorphic bands 46 were shared between at least two individuals and 9 were unique. The average $98.70 \%$ of polymorphism was recorded for all the 11 ISSR primers (Table 1). 
Table.1 Size, number of amplified bands, \% polymorphism, PIC and IPI obtained by ISSR primers

\begin{tabular}{|c|c|c|c|c|c|c|c|c|c|c|}
\hline \multirow[b]{2}{*}{ No. } & \multirow[b]{2}{*}{$\begin{array}{l}\text { ISSR } \\
\text { primers }\end{array}$} & \multirow[b]{2}{*}{$\begin{array}{l}\text { Allele/Band } \\
\text { size (bp) }\end{array}$} & \multirow[b]{2}{*}{$\begin{array}{l}\text { Total No. of } \\
\text { Allele/bands } \\
\text { (A) }\end{array}$} & \multicolumn{3}{|c|}{ No. of Polymorphic bands (B) } & \multirow[b]{2}{*}{$\begin{array}{l}\text { No. of } \\
\text { Monomorphic } \\
\text { bands }\end{array}$} & \multirow[b]{2}{*}{$\begin{array}{l}\% \\
\text { polymorphism } \\
\text { (B/A) }\end{array}$} & \multirow[b]{2}{*}{$\begin{array}{l}\text { PIC } \\
\text { value }\end{array}$} & \multirow[b]{2}{*}{$\begin{array}{l}\text { IPI } \\
(\mathrm{PIC} \times \mathrm{A})\end{array}$} \\
\hline & & & & $\mathrm{S}$ & $\mathrm{U}$ & $\mathrm{T}$ & & & & \\
\hline 1 & UBC-809 & $511-1528$ & 5 & 3 & 2 & 5 & 0 & 100 & 0.781 & 3.90 \\
\hline 2 & UBC-822 & $696-2465$ & 4 & 2 & 2 & 4 & 0 & 100 & 0.666 & 2.66 \\
\hline 3 & UBC-825 & $558-3720$ & 7 & 6 & 1 & 7 & 0 & 100 & 0.818 & 5.72 \\
\hline 4 & UBC-827 & $235-934$ & 6 & 4 & 2 & 6 & 0 & 100 & 0.760 & 4.56 \\
\hline 5 & D2 & $196-1365$ & 5 & 5 & 0 & 5 & 0 & 100 & 0.747 & 3.73 \\
\hline 6 & A830241 & $225-1552$ & 7 & 6 & 0 & 6 & 1 & 85.71 & 0.831 & 5.81 \\
\hline 7 & ISSR 6 & $105-1462$ & 4 & 4 & 0 & 6 & 0 & 100 & 0.706 & 2.82 \\
\hline 8 & ISSR 9 & $295-1641$ & 4 & 4 & 0 & 4 & 0 & 100 & 0.733 & 2.93 \\
\hline 9 & ISSR 13 & $165-1454$ & 5 & 4 & 1 & 5 & 0 & 100 & 0.735 & 3.67 \\
\hline 10 & ISSR 15 & $404-1516$ & 3 & 2 & 1 & 3 & 0 & 100 & 0.571 & 1.71 \\
\hline 11 & ISSR 18 & $223-1500$ & 6 & 6 & 0 & 6 & 0 & 100 & 0.784 & 4.70 \\
\hline Total & & & 56 & 46 & 9 & 55 & 1 & 98.70 & 0.739 & 3.83 \\
\hline
\end{tabular}

$\mathbf{S}=$ Shared; $\mathbf{U}=$ Unique; $\mathbf{T}$ = Total Polymorphic Bands;

PIC = Polymorphism Information Content; IPI = ISSR Primer Index 
Int.J.Curr.Microbiol.App.Sci (2017) 6(4): 79-87

Table.2 Microconidial and macroconidial characters* and Pathogenicity of 10 isolates of $F$. oxysporum f. sp. cumini under in vitro condition

\begin{tabular}{|c|c|c|c|c|c|c|c|c|c|}
\hline \multirow[t]{2}{*}{ Isolate } & \multicolumn{2}{|l|}{ Length $(\mu \mathrm{m})$} & \multicolumn{2}{|l|}{ Width $(\mu \mathrm{m})$} & \multicolumn{2}{|c|}{ No. of septum } & \multicolumn{2}{|l|}{ Shape } & \multirow{2}{*}{$\begin{array}{l}\text { Pathogenicity } \\
\text { Category** }\end{array}$} \\
\hline & Micro & Macro & Micro & Macro & Micro & Macro & Micro & Macro & \\
\hline Vadod & $3.90-15.01$ & $19.90-52.50$ & $2.10-3.26$ & $4.49-6.29$ & $0-1$ & $2-5$ & Oval to oblong & Slightly curved & Medium \\
\hline Pandri & $4.12-17.38$ & $29.00-59.30$ & $2.00-3.32$ & $4.42-6.35$ & $0-1$ & $2-5$ & Oval to reniform & Fusiform & Lower \\
\hline Rajgadh & $3.85-16.45$ & $21.12-55.14$ & $2.30-4.55$ & $4.60-6.00$ & $0-1$ & $2-5$ & Oval to reniform & Slightly curved & Medium \\
\hline Sayla & $4.92-17.01$ & $28.17-44.08$ & $2.13-4.33$ & $4.08-6.14$ & $0-1$ & $2-3$ & Oval to oblong & Fusiform & Lower \\
\hline Dhrangadhra & $4.98-16.22$ & $16.89-44.18$ & $2.10-4.24$ & $4.90-6.55$ & $0-1$ & $3-5$ & Oval to oblong & Slightly curved & Higher \\
\hline Kotada & $3.48-15.90$ & $18.10-56.58$ & $2.00-4.12$ & $4.52-6.37$ & $0-1$ & $2-3$ & Oval to reniform & Slightly curved & Lower \\
\hline Virpur & $4.93-17.00$ & $28.21-45.28$ & $2.05-4.09$ & $4.30-6.10$ & $0-1$ & $2-5$ & Oval to reniform & Fusiform & Medium \\
\hline Kadachh & $4.19-15.90$ & $19.08-50.34$ & $2.29-3.98$ & $4.21-6.32$ & $0-1$ & $2-5$ & Oval to reniform & Slightly curved & Very low \\
\hline Keshod & $3.90-16.00$ & $21.23-57.87$ & $2.21-4.11$ & $4.69-6.45$ & $0-1$ & $2-5$ & Oval to reniform & Fusiform & Lower \\
\hline Junagadh & $4.11-16.98$ & $19.08-50.65$ & $2.00-3.90$ & 4. $65-6.98$ & $0-1$ & $2-5$ & Oval to reniform & Slightly curved & Higher \\
\hline
\end{tabular}

* Mean of 100 conidia

** Higher $75-100 \%$, Medium 50-74\%, Lower 30-49\%, Very low $<30 \%$ 
Table.3 Jaccard's similarity coefficient of Fusarium oxysporum f. sp. cumini isolates based on ISSR data

\begin{tabular}{|c|c|c|c|c|c|c|c|c|c|c|}
\hline & $\begin{array}{l}\vec{z} \\
\frac{0}{2} \\
>\end{array}$ & 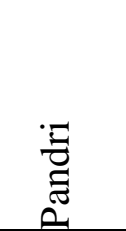 & 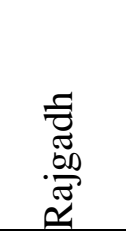 & $\underset{\tilde{N}}{\stackrel{\pi}{\pi}}$ & 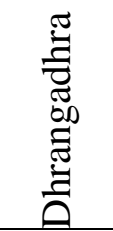 & \begin{tabular}{l}
$\tilde{0}$ \\
\multirow{\pi}{0}{} \\
$\underline{0}$
\end{tabular} & $\stackrel{\Xi}{\Xi}$ & 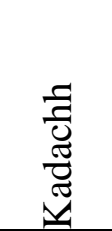 & $\begin{array}{l}\bar{\delta} \\
\frac{\sigma}{\tilde{v}} \\
\mathbb{v}\end{array}$ & 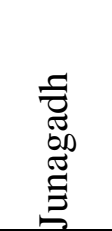 \\
\hline Vadod & 1.000 & & & & & & & & & \\
\hline Pandri & 0.212 & 1.000 & & & & & & & & \\
\hline Rajgadh & $\underline{0.115}$ & 0.370 & 1.000 & & & & & & & \\
\hline Sayla & 0.500 & 0.325 & 0.200 & 1.000 & & & & & & \\
\hline Dhrangadhra & 0.416 & 0.354 & 0.291 & 0.424 & 1.000 & & & & & \\
\hline Kotada & 0.166 & 0.275 & 0.300 & 0.166 & 0.148 & 1.000 & & & & \\
\hline Virpur & 0.161 & 0.257 & 0.222 & 0.361 & 0.259 & 0.380 & 1.000 & & & \\
\hline Kadachh & 0.333 & 0.302 & 0.184 & $\underline{0.605}$ & 0.250 & 0.176 & 0.363 & 1.000 & & \\
\hline Keshod & 0.218 & 0.382 & 0.241 & 0.368 & 0.322 & 0.125 & 0.343 & 0.447 & 1.000 & \\
\hline Junagadh & 0.258 & 0.205 & 0.161 & 0.300 & 0.322 & 0.161 & 0.264 & 0.410 & 0.277 & 1.000 \\
\hline
\end{tabular}

Figure.1 Dendrogram depicting the genetic relationship among 10 Fusarium oxysporum f. sp. cumini isolates based on the ISSR data

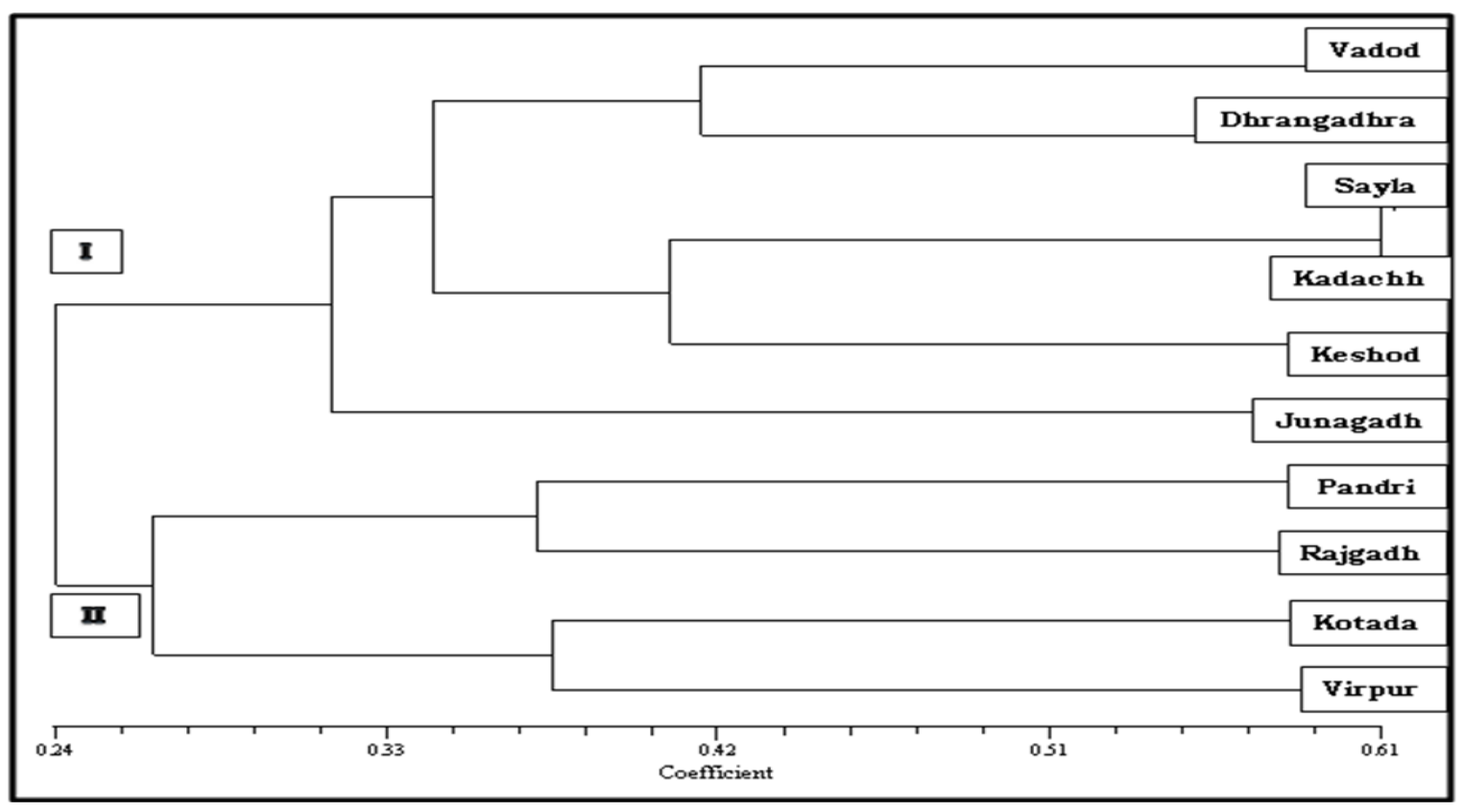


Figure.2 Scanning electron microscope photographs of asexual spores of 10 isolates of $F$. oxysporum f. sp. Cumini
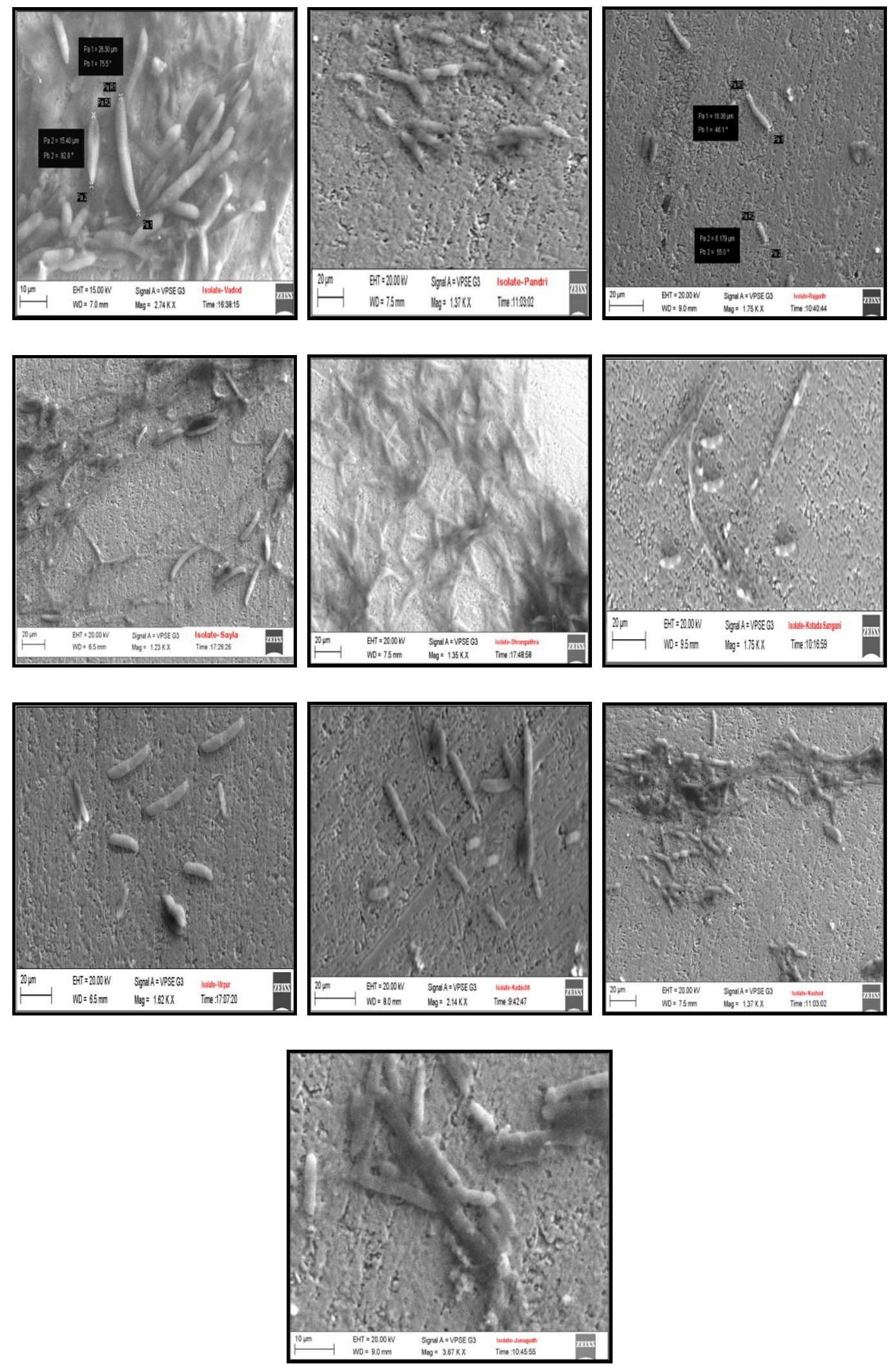
The polymorphic information content (PIC) value ranged from 0.571 (ISSR 15) to 0.831 (A830241) with an average of 0.739 per primer. The ISSR primer index (IPI) varied from 1.71 to 5.81 with an average of 3.83 per primer (Table 2). Two main clusters were generated with the resemblance of $36.33 \%$ and $22.4 \%$ respectively. The cluster I has six isolates including Vadod, Dhrangadhra, Sayla, Kadachh, Keshod and Junagadh. The cluster II consisted of four isolates including Pandri, Rajgadh, Kotada Sangani and Virpur (Fig. 1). Degree of goodness of fit tested by normalized mantel test statistic (Z) i.e. matrix correlation $r=0.8013$ which was found to fall under the category of "good fit".

Isolates from Surendranagar district had 32\% similarity. Out of 5 Surendranagar district isolates 3 (Vadod, Dhrangadhra and Sayla with $44 \%$ similarity) were grouped in cluster I whereas 2 isolates (Pandri and Rajgadh 37\% similarity) in cluster II. Lowest \% (11\%) of similarity was found between same district isolates i.e. Vadod and Rajgadh and highest \% $(60 \%)$ of similarity was found between Sayla and Kadachh isolates. Two isolates from Junagadh district had $27 \%$ similarity grouped in cluster I, while Rajkot district isolates Kotada Sangani and Virpur had 38\% similarity and grouped in cluster II. This indicates presence of correlation between geographic location and clustering of isolates. Similar results were obtained by Mohammadi et al., (2011) in Fusarium oxysporum f. sp. lentis. They partially separated isolates based on their geographical regions. Bayraktar et al., (2008) obtained 99.22\% molecular variance in Fusarium oxysporum isolates within region.

By using spore morphological data; it is very difficult to differentiate between the isolates. However, cultural variability might also arise due to varying environmental or cultural condition. The pathogenicity test indicates presence of variation in virulence among the isolates irrespective of their location. Hence we suggest using Junagadh or Dhrangadhra which have highest virulence isolates to test the disease proneness or susceptibility of cultivars or lines of cumin in future research programmes. This result indicates existence of different races/strains of the cumin wilt pathogen within districts of Saurashtra.

In conclusion genetic characterization of $F$. oxysporum f. sp. cumini is essential for the efficient management of Fusarium wilt through use of resistant cultivars in cumin growing areas. However, an understanding of occurrence, distribution, and genetic relatedness of such pathogenic variants is a necessary for developing effective and efficient integrated disease management.

\section{References}

Anderson, J.A., Churchill, G.A., Sutrique, J.E., Tanksley, S.D. and Sorrels, M.E. 1993. Optimizing parental selection for genetic linkage maps. Genome, 36: 181-186.

Bayraktar, H. and Dolar, F.S. 2011. The molecular identification and genetic diversity of Fusarium species associated with onion fields in Turkey. $J$. Phytopathol., 159: 28-34.

Bayraktar, V., Dolar, F.S. and Maden, M. 2008. Use of RAPD and ISSR markers in detection of genetic variation and population structure among Fusarium oxysporum f. sp. ciceris isolates on chickpea in Turkey. J. Phytopathol., 156(3): 146-154.

Baysal, O., Siragusa, M., Gumrukcu, E., Zengin, S., Carimi, F., Sajeva, M., Jaime, A. and Teixeira, D.S. 2010. Molecular characterization of Fusarium oxysporum f. sp. Melongenae by ISSR and RAPD markers on eggplant. Biochem. Genetics, 48: 524-537. 
Booth, E. 1971. The genus Fusarium. Commonwealth Mycological Institute, Kew, Survey, England.

Dhartiben, B., Kapadiya, Bhumika, K., Dabhi and Kishorkumar, D., Aparnathi. 2016. Spices and Herbs as a Source of Natural Antioxidants for Food. Int. J. Curr. Microbiol. App. Sci., 5(7): 280- 288. doi:

http://dx.doi.org/10.20546/ijcmas.2016. 507.029

Haware, M.P., Nene, Y.L. and Natarajan, M. 1996. Survival of Fusarium oxysporum f. sp. ciceri in soil in the absence of chickpea.

Mediterranean, 35: 9-12.

Phytopathologia

Mohammadi, N., Goltapeh, E.M., Babaie, A. and Puralibaba, H. 2011. Pathogenic and genetic characterization of Iranian isolates of Fusarium. oxysporum f. sp. lentis by ISSR analysis. J. Agri. Technol., 7(1): 63-72.

Murray, M.G. and Thompson, W.F. 1980. Rapid isolation of high molecular weight DNA. Nucleic Acids Res., 8: 4321-4325.

Nawade, B.D., Jadeja, K.B., Talaviya, J.R. and Vyas, U.M. 2014. Comparative Analysis of Fusarium oxysporum f. sp. cumini Isolates Using RAPD Marker and Cultural Characteristics. Trends in Biosci., 7(17): 2475-2478.
Nelson, P.E., Toussoun, T.A. and Marasas, W.F.O. 1983. Fungal Species an illustrated manual for identification. Pennsylvania State University, UK.

Patel, P.N., Prasad, N., Mathur, R.L. and Mathur, B.L. Fusarium wilt of cumin. 1957. Curr. Sci., 6: 181-182.

Ramchandra, S. Suthar and Bhatt, P.N. 2011. Morphological and molecular identification of Fusarium isolated from cumin wilt. Internat. J. Plant Protec., 4(2): 359-362.

Rohlf, J.F. 1998. NTSYS-PC: Numerical taxonomy and multivariate analysis system. Version 2.01. Setauket, NY: Exeter software.

Sambrook, J., Russell, D.W., Irwin, N. and Janssen, K.A. 1989. Molecular cloning: A laboratory manual, $3^{\text {rd }}$ Edi 1, 69-98.

Selim, M.E. and Zanaty, F.M. 2014. Discrimination of different pathogenic Fusarium oxysporum isolates based on virulence and intergenomic-spacer sequences (IGS). Int. J. Curr. Microbiol. App. Sci., 3(11): 157-165.

Spices Board. http://www.indianspices.com/ 2016.

Talaviya, J.R., Jadeja K.B. and Nawade, B.D. 2014. Variability Among Different Isolates of Fusarium oxysporum f. sp. Cumini. Trends in Biosci., 7: 36113616.

\section{How to cite this article:}

Bhagwat Nawade, J. R. Talaviya, U.M. Vyas, K.B. Jadeja and Golakiya, B.A. 2017. Diversity Analysis among Fusarium oxysporum F. Sp. cumini Isolates Using ISSR Markers, Spore Morphology and Pathogenicity. Int.J.Curr.Microbiol.App.Sci. 6(4): 79-87. doi: https://doi.org/10.20546/ijcmas.2017.604.010 